\title{
Economic analysis of two kinds of water heaters in service industry
}

\author{
Chunhua Liu, ${ }^{1, *}$, Yulei Zhao ${ }^{2}$, and Zhuangzhuang $\mathrm{Qu}^{1}$ \\ ${ }^{1}$ Shandong Huayu Institute of technology, R \& D center of building energy saving engineering technology, Dezhou City, Shandong \\ Province \\ ${ }_{2}^{2}$ Jiangsu micoe solar energy co.,ltd, Lianyungang City, Jiangsu Province
}

\begin{abstract}
Taking a barber shop in Dezhou City of Shandong Province as an example, this paper calculates the required heat by using 300 liters of $40{ }^{\circ} \mathrm{C}$ hot water every day, introduces the working principle and system characteristics of electric water heater and solar water heater, selects the mainstream products in the market, and calculates the use cost. The comparison shows that the price of electric water heater is low, but the annual cost is high; the price of solar water heater is high, but the annual cost is low.
\end{abstract}

\section{Introduction}

There are three kinds of water heaters in China's water heater Market: gas water heater, electric water heater and solar water heater. Among them, gas and electric water heaters account for the vast majority of China's water heater market share. The author investigated a number of barber shops in Dezhou City. Most of the commercial houses have no gas pipeline, so they all use electric water heater. Taking a small barber shop in Dezhou City of Shandong Province as an example, this paper analyzes the working principle, system characteristics, product price and use cost of electric water heater and solar water heater ${ }^{[1]}$. The building where the barber shop is located is a six story Street building, and our shop is located on the first floor.

The monthly average temperature of tap water in Dezhou in 2019 is shown in Table 1.

Table 1. Average monthly water temperature of Dezhou City in 2019

\begin{tabular}{|c|c|c|c|c|c|c|c|c|c|c|c|c|}
\hline Month & 1 & 2 & 3 & 4 & 5 & 6 & 7 & 8 & 9 & 10 & 11 & 12 \\
\hline Temperature $/{ }^{\circ} \mathrm{C}$ & 2.4 & 3.1 & 6.6 & 11.6 & 18.5 & 24.3 & 27.3 & 28.6 & 23.6 & 16.8 & 10.2 & 4.3 \\
\hline
\end{tabular}

Through field investigation, the owner's daily water consumption is about 300 liters, and the annual heat demand is $\mathrm{Q}$.

Where:

$$
\mathrm{Q}=\mathrm{C}_{\mathrm{p}} \mathrm{v}_{\rho}\left(\mathrm{t}_{\mathrm{r}}-\mathrm{t}_{\mathrm{p}}\right) \mathrm{n} / 1000
$$

$\mathrm{Q}$ - heat required for heating water (MJ);

$C_{p}$ - specific heat of water at constant pressure, $C_{p}=$ $4.2 \mathrm{~kJ} /(\mathrm{kg} \cdot \mathrm{K})$;

$\mathrm{v}$-daily water consumption $\left(\mathrm{m}^{3}\right), \mathrm{v}=0.3 \mathrm{~m}^{3}$;

$\rho$ - density of water, $\rho=1000 \mathrm{~kg} / \mathrm{m}^{3}$;

$\mathrm{T}_{\mathrm{r}}$ - hot water temperature, $\mathrm{TR}=40{ }^{\circ} \mathrm{C}$;

$\mathrm{T}_{\mathrm{IP}}$ - annual average temperature of cold water, $\mathrm{T}_{\mathrm{lp}}=$ $14.8^{\circ} \mathrm{C}$;

$\mathrm{n}$-annual water consumption days, $\mathrm{n}=355$ days.

Substituting the above parameters into formula (1), q $=11272 \mathrm{MJ}$.

\section{Contrast}

\subsection{Electric water heater}

\subsubsection{Working principle and system characteristics}

Electric water heater uses electric heater to convert electric energy into heat energy to heat cold water. The mainstream product on the market is pressure storage type electric water heater, and the working principle is shown in Figure 1. The water tank can bear the pressure of $0.6 \mathrm{MPa}$, and can supply water for many ways and long distance; the water tank has polyurethane insulation layer, and the hot water can be stored for a long time ${ }^{[2]}$. The electric water heater has the function of automatically starting and stopping heating according to the temperature change, with accurate temperature control; the installation position is flexible, generally installed near the shampoo, with less cold water in the

\footnotetext{
*Corresponding author: 274466502@qq.com
} 
pipeline, small fluctuation of water temperature when using, and high comfort; the water tank is easy to accumulate scale and impurities after long-term use, so it is necessary to regularly clean the scale and replace the magnesium $\operatorname{rod}^{[3]}$.

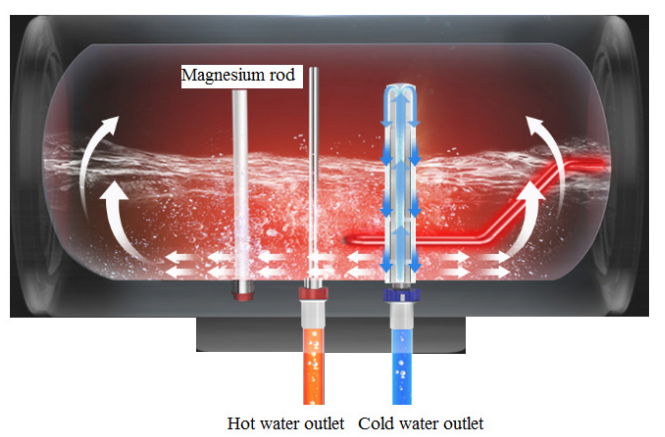

Fig. 1. Working principle of pressure storage type electric water heater

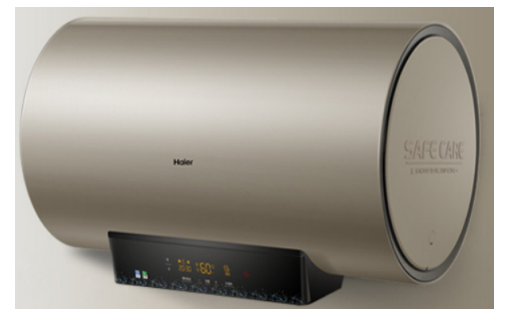

Fig. 2. Appearance of Haier electric water heater

\subsubsection{Product price and use cost}

A Haier ES80H3D fast heating electric water heater is selected. The product appearance is shown in Figure 2, and its model parameters are shown in Table 2 . According to the official website of Jingdong, the selling price is 2400 yuan / set. Due to the small number of accessories required, the cost is not included.

Table 2. Model parameters of Haier electric water heater

\begin{tabular}{|c|c|}
\hline Product model & ES80H3D \\
\hline Installation dimension & 80 \\
\hline $\mathrm{L} \times \mathrm{W} \times \mathrm{H}(\mathrm{mm})$ & $890 \times 575 \times 555$ \\
\hline Maximum volume & 3 \\
\hline
\end{tabular}

The general industrial and commercial households in Dezhou adopt the time of use charging mode. According to the notice of Shandong Provincial Price Bureau and Shandong Provincial Economic and Information Commission on improving the policy of peak valley time of use electricity price, the charging prices for specific periods are shown in Table 3.

Table 3. Time sharing charges in Dezhou City

\begin{tabular}{|c|c|c|c|}
\hline Time interval & Duration/h & Electricity price/kW·h & Remarks \\
\hline The day before 23:00-7:00 & 8 & $¥ 0.3249$ & Valley section \\
\hline $7: 00-8: 30$ & 1.5 & $¥ 0.6226$ & Flat section \\
\hline $8: 30-11: 30$ & 3 & $¥ 0.9203$ & Peak section \\
\hline $11: 30-16: 00$ & 4.5 & $¥ 0.6226$ & Flat section \\
\hline $16: 00-21: 00$ & 5 & $¥ 0.9203$ & Peak section \\
\hline $21: 00-23: 00$ & 2 & $¥ 0.6226$ & Flat section \\
\hline
\end{tabular}

According to the survey, the working hours of the merchant are 10:00-22:00, of which 12:00-14:00 is the rest time. The water consumption is averaged to each working period, and the daily average electricity price is 0.8161 yuan $/ \mathrm{kW} \cdot \mathrm{h}$.

According to the average electricity price $\mathrm{P}$, the annual electricity charge $t$ is calculated.

$$
\mathrm{t}=\mathrm{P} \times \mathrm{Q} /\left(3.6 \eta_{\mathrm{d}}\right)
$$

Where:

t-annual electricity charge (yuan);

Q-heat required for heating water (MJ), taking 11272 $\mathrm{MJ}$; $95 \%$
P-electricity price, $\mathrm{P}=0.8161$ yuan $/ \mathrm{kW} \cdot \mathrm{h}$.

Substituting the above parameters into formula (2), $\mathrm{t}$ $=2690$ yuan is calculated.

\subsection{Solar heater}

\subsubsection{Working principle and system characteristics}

Solar energy is a clean energy, and solar water heater has the outstanding advantages of safety, convenience, environmental protection and energy saving. The production, installation and retention of solar water heaters in China rank the first in the world ${ }^{[4]}$. Solar water heater is mainly classified according to the form of collector, which is divided into vacuum tube solar water 
heater and flat plate solar water heater. Dezhou City belongs to the cold winter and hot summer area, mainly installed with vacuum tube solar water heater. According to the connection form of the collector and the water tank, the solar water heater can be divided into split type and integrated type ${ }^{[5]}$. The external structure of the integrated vacuum tube solar water heater is shown in Figure 3. All glass vacuum solar collector tube is called vacuum tube for short. It uses the solar selective absorption coating on the outer wall of the inner tube to convert the solar energy into heat energy and slowly heat the cold water in the vacuum tube and water tank $\mathrm{k}^{[6]}$. The water tank is used to store cold and hot water. The solar energy used in this paper is an integrated vacuum tube solar water heater.

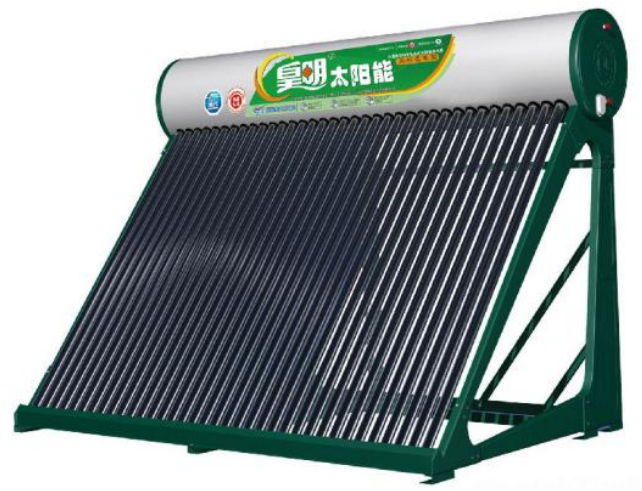

Fig. 3. External structure of integrated vacuum tube solar water heater

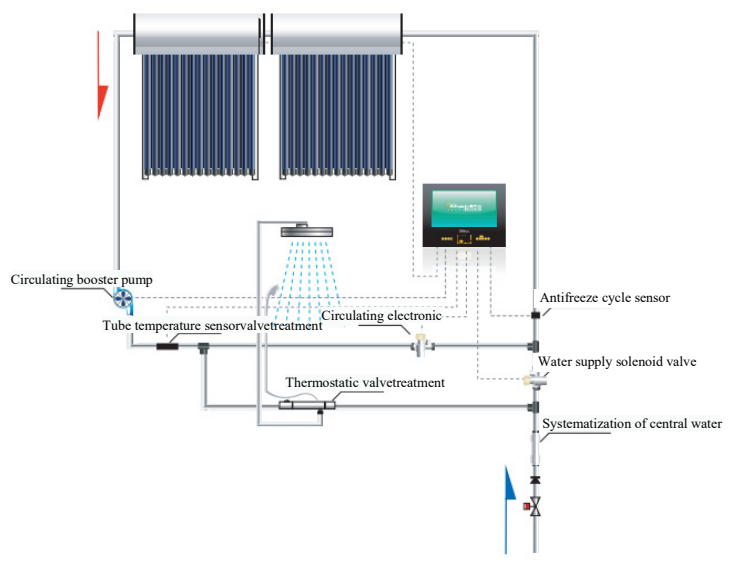

Fig. 4. Installation pipeline diagram of solar water heater

The product is installed on the roof of the building, and the daylighting of the collector can not be blocked for a long time, especially during 10:00-16:00; the water temperature rises slowly in rainy days, so the electric auxiliary heating device needs to be installed in the water tank; the solar water tank is installed outdoors, which does not occupy the indoor space; the system adopts the way of pipe falling into the water ${ }^{[8]}$. In order to ensure the comfort of water use, the circulating booster pump needs to be installed, which can increase the energy consumption Hot water pressure, improve comfort, can also be stored in the pipeline for a long time in the cold water circulation back to the tank, put an end to the pipeline cold water; in summer when the water consumption is small, the water heater will overheat, affect the life of the product; in winter, the environment temperature is low, need to install electric heating belt for outdoor pipeline, pipeline antifreeze; pipeline need to pass through the flue, can not be installed on the external wall of the buildin ${ }^{[7]} \mathrm{g}$.

\subsubsection{Product price and use cost}

Select 2 solar water heaters with integrated vacuum tube of Huangming Q-B-J-1-155/2.10/0.05-1. See Table 4 for product model parameters. The solar water heater is arranged in series, and the installation pipeline is shown in Table 4. Each water heater is 2800 yuan, and the auxiliary facilities such as water pump, upper and lower water pipe, electric tracing belt, display and control system need about 1600 yuan, totaling 7200 yuan.

Table 4. model parameters of solar water heater

\begin{tabular}{|c|c|}
\hline Product model & Q-B-J-1-155/2.10/0.05-1 \\
\hline $\begin{array}{c}\text { Installation dimension } \\
(\text { East West } \times \text { North South } \times \\
\text { Height mm })\end{array}$ & 16 \\
\hline $\mathrm{L} \times \mathrm{W} \times \mathrm{H}(\mathrm{mm})$ & $1405 \times 1631 \times 1975$ \\
\hline Water capacity $/ \mathrm{L}$ & 155 \\
\hline
\end{tabular}

Considering the water use habits of barber shops and the continuous cloudy days, the electric auxiliary heating device in the water tank needs to be started about $15 \%$ of the time in a year. According to the electricity consumption of the electric water heater, the electricity charge is about 404 yuan / year.

\section{Economic analysis and comparison}

Compare the cost of the two water heaters, see Table 5. The price of electric water heater is low, the initial investment is small, but the annual operation cost and annual cost are high; the price of solar water heater is high, the initial investment is large, but the annual operation cost and annual cost are low.

Table 5. Comparison of water heater cost

\begin{tabular}{|c|c|c|c|c|}
\hline Type & Product price/yuan & $\begin{array}{c}\text { Annual operating } \\
\text { cost/yuan }\end{array}$ & Service life/year & $\begin{array}{c}\text { Annualized cost } \\
\text { (yuan / year) }\end{array}$ \\
\hline Electric water heater & 2400 & 2690 & 8 & 2990 \\
\hline Solar heater & 7200 & 404 & 15 & 884 \\
\hline
\end{tabular}




\section{Comparison of water temperature stability}

The electric water heater is generally of volumetric type. After heating a tank of water, the temperature is higher (up to $80 \mathrm{C}$ ) at the beginning of use. In the process of use, the heated water is ejected by cold water. At the same time, the cold and hot water in the tank are continuously mixed, and the water temperature is gradually reduced until it is all cold water ${ }^{[9]}$. Therefore, in use, it is necessary to constantly adjust the proportion of cold water and hot water, which is not convenient to use. If you want to make the water temperature relatively stable, you should always turn on the electric heating, which may cause waste in the end.

The water tank of solar water heater (household type) has large capacity and constant water temperature, which is convenient to use, but the water in the pipe needs to be discharged first.

\section{Safety comparison}

Electric water heater should pay attention to leakage phenomenon, leakage protection device should be normal and effective.

The solar water heater is safe and convenient to use.

\section{Comparison of investment price and use and maintenance cost}

Solar water heater (household type) 140 liters, heat collection area of $2 \mathrm{~m}^{2}$, the general price of more than 4000 yuan (installation also consider lightning protection). The cost of use varies. According to the current price of 1.6 yuan per cubic meter of natural gas and 0.54 yuan per kilowatt hour of electricity, the heat of 1 cubic meter of natural gas is $3.971 \times 104 \mathrm{~kJ}$, the heat of 1 kilowatt hour of electricity is $300 \mathrm{~K}$, the thermal efficiency of natural gas is $80 \%$, the thermal efficiency of electricity is $90 \%$, the heat required to heat 1 liter of water from $14{ }^{\circ} \mathrm{C}$ to $50{ }^{\circ} \mathrm{C}$ is $150.5 \mathrm{~kJ}$, the average daily consumption of three members of a family is 80 liters of hot water, the annual consumption of hot water is 29.2 tons, and the energy consumption is $4394 \times 103 \mathrm{~J}$, The cost is 220 yuan and 732 yuan respectively. Compared with natural gas water heater, solar water heater can save $80 \%$ of the cost.

The service life of the electric water heater is about 10 years. The magnesium rod used to prevent the corrosion of the inner tank needs to be replaced every 2 years, and the cost of each replacement is about 60 yuan. The service life of the solar water heater (household type) is about 10 years, and the maintenance and repair cost of system sewage and collector dust removal is about 20 yuan per year. After comprehensive calculation, the cost of electric water heater is 37.4 yuan per ton of hot water, and the cost of solar water heater (household type) is 17.4 yuan per ton of hot water.

\section{Heating rate comparison}

The electric water heater needs to be electrified for half an hour to one hour before it can be used. If the tank runs out of water, reheat it. If the amount of water, bath time is not good, a box of water has not finished the bath, then you have to wait in the bathroom for a period of time.

The solar water heater (household type) heats the water in sunny weather without reheating. It takes several hours to use auxiliary electric heating in rainy weather.

\section{Conclusion}

Through this paper, we can see that the electric water heater occupies a dominant position in the domestic water heater market because of its low price, easy installation and use. However, due to the fact that users can not enjoy the low electricity price during the valley period ${ }^{[9]}$, the cost of hot water manufacturing is on the high side. Solar water heater has a prominent cost advantage in places where a large number of hot water is used. It needs to continue to improve the comfort and reliability of the system in order to have a broader market.

\section{Acknowledgments}

This paper is supported by R\&D center of building energy saving engineering technology of Shandong Huayu University of Technology.

\section{References}

1. Gao min. water heater industry: opportunities and challenges, breaking the situation at present [J]. Modern household appliances, 2020 (01): 54-56

2. Wang Chunhui. Market investigation and analysis of gas water heaters in Tangshan [J]. Energy saving, 2018, (2): 89-92

3. Yang Ling. Research on domestic marketing strategy of flat panel solar water heater of company a [D]. South China University of technology, 2019

4. Li Dapeng, Wang Yufan, Liu Gang, Liao Shengming, Liu Xianping. Effect of shading on thermal performance of solar water heater [J]. Journal of Central South University, 2020,27 (04): 1273-1289

5. Qiu Shoufeng. The history and causes of the shrinking solar water heater market [J]. Energy and environment, 2014 (06): 47-48 + 50

6. Xu Youjin, Li Zhengrong, Huang Junpeng, Chen J iaoyun. Investigation and analysis of urban residential solar water heating system [J]. Solar energy, 2019 (01): 9-16

7. Li Yefa. Analysis of economic benefit of solar water heater by interpolation method [J]. Acta solar energy Sinica, 2001,22 (4): 448-450 
8. G.L. Morrison, T. Anderson and M. Behnia. Seasonal Performance Rating of Heat Pump Water Heaters. Sydney: The University of New South Wales, 2004.

9. Graham Morrison. Heat Pump Water Heaters. S ydney: The University of New South Wales,2004. 